\title{
Global Law as Translated Text: Mapping Institutional Legal Translation
}

\author{
Fernando Prieto-Ramos \\ Centre for Legal and Institutional Translation Studies (Transius), \\ Faculty of Translation and Interpreting, University of Geneva \\ fernando.prieto@unige.ch
}

\begin{abstract}
As international organizations rely on translation to produce and enforce legal instruments in multiple languages, global law can be regarded as a network of translated texts. To shed light on the multilingual dimension of international and supranational law, this study presents an interdisciplinary mapping of legal genres in three representative settings: the $\mathrm{UN}$, the WTO, the $\mathrm{EU}$, and their respective adjudicative bodies. Genres are classified under three text typologies corresponding to three categories of legal procedures and text production: law-making, compliance monitoring and adjudication. The resulting taxonomies and their legal contextualization reveal important commonalities as regards the interconnection between legal text-types and functions, as well as differences that reflect the nature of each institutional legal system, including variations in the level of multilingualism. This mapping is considered a condition for further investigations into the scope and features of institutional legal translation, with the ultimate aim of improving its quality.
\end{abstract}

\section{Keywords}

institutional legal translation - international law - EU law - law-making - compliance monitoring - adjudication - legal genres - text typologies

In a globalized world where people, trade and ideas move fluidly across borders, international rules are fundamental for the functioning of society, and

(C) FERNANDO PRIETO-RAMOS, 2017 DOI 10.1163/22112596-02201009

This is an open access article distributed under the terms of the prevailing CC-BY-NC license at the time of publication. 
multilateral cooperation is the primary means for addressing common global challenges, such as poverty, migration and climate change. In this context, global law has gained new significance as it has evolved into a multi-layered network of rule-making and implementation mechanisms that interface at regional, national and local levels.

To understand how international and supranational law develops, it is necessary to consider the actors, systems and processes by whom and through which law is generated. This entails acknowledging contemporary law as the 'product of a subtle and evolving interplay of law-making instruments, both binding and non-binding, and of customary law and general principles'; 1 and taking into account the creation, application and interpretation of norms. The three interrelated contexts, i.e., law-making, compliance monitoring and adjudication, come into play in the development of international and supranational law; they cannot be studied in isolation, since the processes of interpretation and application by judicial tribunals ${ }^{2}$ also contribute to defining global law. ${ }^{3}$

This paper focuses on the linguistic dimension of these legal procedures as contexts in which multilingual texts are produced through translation. If we think of law as a matter of language or speech acts, ${ }^{4}$ or as a matter of communication, ${ }^{5}$ it follows that global law is also a matter of multilingual communication and institutional legal translation. Intergovernmental and supranational institutions rely on translation to create, disseminate, enforce and interpret legal instruments in different languages, according to varying degrees of multilingualism. Institutional translators are key actors responsible for giving linguistic shape to authentic texts which ultimately become sources of law' ${ }^{6}$ They must integrate substantive and procedural legal knowledge into decision making, and cooperate with legal experts involved in text production and interpretation. It can be argued that the shared goal for translated multilingual law is its uniform interpretation and application. ${ }^{7}$ This affirms the

1 Alan Boyle and Christine Chinkin, The Making of International Law (Oxford University Press 2007) vii.

2 Abdul G. Koroma, 'International Courts and Tribunals: Alternatives to Treaty Making' in Volker Röben and Rudiger Wolfrum (eds), Developments in International Law in Treaty Making (Springer 2005) 621.

3 Bruno Simma, 'Commissions and Treaty Bodies of the UN System' in Volker Röben and Rudiger Wolfrum (eds), Developments in International Law in Treaty Making (Springer 2005) 581.

4 See, e.g., Marianne Constable, 'Law as Language' (2014) 1 Critical Analysis of Law 63.

5 See, e.g., Mark Van Hoecke, Law as Communication (Hart Publishing 2002).

6 Fernando Prieto-Ramos, 'International and supranational law in translation: From multilingual lawmaking to adjudication' (2014) 20 The Translator 313.

7 Susan Šarčević, New Approach to Legal Translation (Kluwer Law International 1997) 73. 
value of viewing the fabric of global law as a network of translated texts from different institutional legal systems.

From the interdisciplinary perspective of Legal Translation Studies (LTS), the above classification of legal procedures and text production contexts (lawmaking, compliance monitoring and adjudication) is particularly relevant for a translation-oriented description of text-types. ${ }^{8}$ In a multidimensional categorization of legal texts, text typologies share comparable text producers and purposes, and comprise a diversity of legal genres that realize more specific legal functions and discursive patterns. ${ }^{9}$ In the case of the three categories in point, legal genres are textual manifestations of the governance of international relations and the application of legal norms according to established institutional conventions. Hence, the description of text typologies and genres stands as a pivotal step in the legal translation process. It is also essential for defining the scope and features of institutional legal translation more generally.

To that end, this study presents a mapping of legal texts translated in international institutional settings according to the above threefold classification. These categories were identified as key legal contexts of text production that contribute to the development of international and supranational multilingual law. This means that institutional documents translated for housekeeping or other administrative purposes (e.g. private contracts or job advertisements) were not considered relevant to the purpose of this paper. The main aim of this study is to establish and legally contextualize a map of key genres of translated global law as the first stage of a larger project on the scope, strategies and quality perceptions of institutional legal translation ${ }^{10}$ in three representative settings: the United Nations (UN) as 'mother' organization that covers a broad range of issues, the European Union (EU) as a unique supranational legal order, and the World Trade Organization (WTO) as a specialized rule-making organization; and their respective adjudicative bodies. In the case of the UN, only the texts produced by the International Court of Justice (ICJ), as the main judicial body of the organization, were considered under adjudication procedures. Given their specific mandates, ad hoc criminal tribunals established by the Security Council, ${ }^{11}$ as well as independent courts such as the International

8 Prieto-Ramos (n 6) 315-316.

9 Fernando Prieto-Ramos, 'Legal Translation Studies as Interdiscipline: Scope and Evolution' (2014) 59 Meta: Translator's Journal 260.

10 'Legal Translation in International Institutional Settings: Scope, Strategies and Quality Markers (LETRINT)' (Consolidator Grant, 2015-2020).

11 See the integrated gateway to the documentation of the International Criminal Tribunal for the former Yugoslavia (1993-2017), the International Criminal Tribunal for Rwanda 
Criminal Court or the International Tribunal for the Law of the Sea, initially established by un conventions, fall outside the scope of the study.

After a brief description of the language regimes of these institutions, our textual mapping will lead to a taxonomy of institutional legal genres classified by text category and organization. A comparative table will summarize the results of the contextualization in each legal setting. Finally, these results will be discussed to support conclusions on the similarities and differences between the three organizations, particularly regarding the prominence and interrelation of the different text-types and the extent to which they reflect the singularities of each legal system.

For this mapping, data on legal genres were gathered through a process of verifying the institutional documents available on the relevant institutional databases (including the UN's Official Document System, WTo's Documents Online, EU's EUR-Lex, the CJEU's InfoCuria database and several thematic gateways); the results were cross-checked with informants from the institutions surveyed to validate the taxonomies. Internal drafts or confidential documents, which are not always translated into all the official languages, were considered secondary to the main legal genres, and hence excluded from the taxonomies. However, the mapping does include certain texts that are not systematically available to the public but summarized for translation and publication purposes, mostly in the case of the EU. Finally, macro-genres such as reports or press releases produced by the relevant institutional legal bodies were considered legal sub-genres if they dealt with legal matters and include legal discursive features. ${ }^{2}$ Press releases, summaries and certain administrative reports were therefore included in the taxonomies of main genres when they were regarded by institutional sources as relevant informative documents in the legal procedures studied, whereas purely instrumental documents such as meeting agendas were systematically considered secondary.

Legal translation is a common denominator in law creation, application and interpretation in the three institutional settings under scrutiny, but under different language regimes. The Eu's language regime, currently consisting of 24 official languages, is unique in comparison to the regimes of other international

(1994-2015) and the Mechanism for International Criminal Tribunals (2010-): <http:// www.unmict.org/en>, accessed 30 December 2016. 
organizations. The United Nations uses six official languages, while the World Trade Organization has only three: English, French and Spanish. There are important legal reasons for this difference, the main being the principles of direct effect and primacy of Eu law.

The $\mathrm{EU}$ is more than just an international organization. In Van Gen den Loos, ${ }^{13}$ the Court of Justice of the EU (CJEU) stated that 'the Community constitutes a new legal order of international law for the benefit of which the states have limited their sovereign rights, albeit within limited fields, the subjects of which comprise not only Member States but also their nationals.' It decided that 'independently of the legislation of the Member States, Community law therefore not only imposes obligations on individuals but is also intended to confer upon them rights which become part of their legal heritage. ${ }^{14}$ As a consequence, the EU, unlike the UN and WTO, passes legislation that is directly applicable on its Member States and their citizens.

In addition, the CJEU further elaborated on the legal nature of the $\mathrm{EU}$ in Costa $v$ ENEL. ${ }^{15}$ The Court confirmed that: 'By contrast with ordinary international treaties, the EEC Treaty has created its own legal system which, on the entry into force of the Treaty, became an integral part of the legal systems of the Member States and which their courts are bound to apply'. ${ }^{16}$ The Court considered that 'the law stemming from the Treaty' was 'an independent source of law' and 'could not, because of its special and original nature, be overridden by domestic legal provisions.' ${ }^{17}$ Therefore, where two sets of rules can apply to a situation, EU law must take precedence.

Since EU law produces rights and obligations for individuals, it is both a legal obligation and a practical necessity for the EU to provide citizens with legislation in their own languages. In addition to enabling citizens to understand the legislation addressed to them, multilingual legislation reflects an existing political situation, as well as the desired equal treatment of different people and linguistic groups. Equal treatment is, of course, a very important issue in the context of the EU as well, since it touches upon the acceptability of the EU as an organization and of the legislation it adopts. ${ }^{18}$

\footnotetext{
13 Case C-26/62 Van Gend en Loos [1963] ECR 1.

14 Ibid 1212.

15 Case C-6/64 Costav ENEL [1964] ECR 66.

16 Ibid 593 .

17 Ibid 594.

18 Some authors have remarked that equal language rights are afforded only to the official languages and not to others. This has raised considerable debate around minority languages that enjoy official status within particular Member States.
} 
The European Commission stated that one of the aims of the policy on multilingualism is 'to give citizens access to European Union legislation, procedures and information in their own languages' ${ }^{19}$ Citizens in the EU are directly affected by the European integration process. The situation is different in the UN or the WTO, where citizens mainly look from the side-lines at the action taken by governments on their behalf. The што, in particular, has refused to add languages to its regime despite increasing pressure from new Member economies since the 2000 (especially after China's accession to the wTO in 2001 and the Russian Federation's accession in 2012). ${ }^{20}$ This means that international trade agreements and all wTO documentation related to their application relies more on translation by Members at national level and less on the WTO's language services. It also entails further 'linguistic distance' in the communication of WTO policies around the globe, as opposed to the UN policies which are communicated in six official languages. Last but not least, it raises questions about traditional and new political and linguistic (un)balances that call for a dedicated study.

In the case of the corresponding judicial bodies, language policies also vary. Dispute settlement at the WTO is governed by the same language regime as in the other areas of the organization's work. At the CJEU, however, judgments have only one authentic language version, which is the language of the case. ${ }^{21}$ The other versions are 'translations', as opposed to translated EU legislation, which is authentic in all official languages.

As for the International Court of Justice (ICJ), the Registry publishes the decisions of the Court in both English and French, ${ }^{22}$ which are the official languages of the institution. According to Article 39 of the ICJ Statute, the Court determines which is the authoritative language on a case-by-case basis. If the parties agree on the language to conduct the case, the judgment is delivered in that language (and also published in the other official language). If they do not agree, the parties can use the language they prefer in their pleadings, and even

$19 \operatorname{com}(2005) 596$ final, page 3.

20 At a press conference held on 16 December 2011, the then Director-General of the WTo, Pascal Lamy, referred to budgetary constraints as the main reason not to add Russian or other languages (particularly Chinese and Arabic) to the three wто official languages. See: $<$ http://www.nytimes.com/2011/12/17/business/global/wto-accepts-russia-bid-to-join .html $>$, accessed 6 February 2017.

21 Article 41 of the Rules of Procedures of the Court: "The texts of documents drawn up in the language of the case or, where applicable, in another language "authorised" pursuant to Articles 37 or 38 of these Rules shall be authentic'.

<http://www.icj-cij.org/publications/index.php?p1=8>, accessed 30 November 2016. 
when they mainly use the same language, the Court determines 'which of the two texts shall be considered as authoritative' (Article 39.2 of the ICJ Statute).

\section{$3 \quad$ Text Production in Law-Making Procedures}

Law-making will be considered in the broad sense, including legally binding instruments (hard law) and non-binding instruments (soft law) that may attain some degree of legal force (e.g., recommendations or declarations). These instruments constitute the backbone of each legal system in the pursuit of specific policy objectives. As pointed out in the introduction, drafts and preparatory documents were considered secondary to the final instruments produced in this setting.

\subsection{Law-Making at the UN}

Although the UN was not conceived as a legislative body, one of its main objectives is to promote the development of international law. The multilateral 'norm-creating' treaty is the 'most obvious instrument of law-making in the UN system. ${ }^{23}$ Hundreds of such instruments have been negotiated and adopted by UN organs. ${ }^{24}$ As noted by Zhao and Cao, these instruments 'are in constant proliferation' and their translation 'is the most common task undertaken by the UN translators. ${ }^{25}$

In addition, resolutions adopted by the General Assembly, the Security Council and the Economic and Social Council (ECOSOc) may attain some degree of legal force. The UN Charter endows the General Assembly with the right to make recommendatory resolutions ${ }^{26}$ to the UN Member States or

23 Oscar Schachter, 'The un Legal Order: An Overview' in Christopher C. Joyner (ed), The United Nations and International Law (Cambridge University Press 1997) 4.

24 This study does not cover instruments produced by the autonomous specialized agencies of the UN system. On law-making by Un specialized agencies, see, e.g., Barbara K. Woodward, Global Civil Society in International Lawmaking and Global Governance. Theory and Practice (Martinus Nijhoff 2010) 272.

25 Xingmin Zhao and Deborah Cao, 'Legal translation at the United Nations' in Anabel Borja-Albi and Fernando Prieto-Ramos (eds), Legal Translation in Context: Professional Issues and Prospects (Peter Lang 2013) 203, 204.

26 On the discussion about 'declaratory resolutions', see Oscar Schachter, International Law in Theory and Practice (Martinus Nijhoff 1991). On the legal significance of the General Assembly's declarations, also see Obed Y. Asamoah, The Legal Significance of the Declarations of the General Assembly of the United Nations (Martinus Nijhoff 1966), and Gregorio Garzón Clariana, 'El valor jurídico de las declaraciones de la Asamblea General de las 
the Security Council. 'Textually interpreted,' these recommendations 'would exclude binding force. ${ }^{27}$ However, this does not mean that General Assembly resolutions are deprived of legal effects. They are generally non-binding on Member States, but can be binding on the internal operations of the General Assembly itself. General Assembly resolutions have also 'influenced the evolution of treaties, general principles, and customary law'. ${ }^{28}$ In the Nuclear Weapons Advisory Opinion, ${ }^{29}$ the ICJ stated that:

General Assembly resolutions, even if they are not binding, may sometimes have normative value. They can, in certain circumstances, provide evidence important for establishing the existence of a rule or the emergence of an opinio juris. To establish whether this is true of a given General Assembly resolution, it is necessary to look at its content and the conditions of its adoption; it is also necessary to see whether an opinio juris exists as to its normative character. Or a series of resolutions may show the gradual evolution of the opinio juris required for the establishment of a new rule. ${ }^{30}$

All in all, although the General Assembly is not a legislative body, it fulfils a pivotal role in the development of international law due to its ability to adopt resolutions in matters falling within the Charter's scope, convene law-making conferences, adopt treaties and initiate codification projects. ${ }^{31}$

The different committees and subsidiary bodies of the General Assembly also play a prominent role in law-making and the negotiation of multilateral treaties in specific areas, and report to the plenary. The Sixth Committee (Legal) of the General Assembly and the International Law Commission (ILC)

Naciones Unidas' (1973) 72 Revista Jurídica de Cataluña 581. For the distinction between 'recommendations' and 'declarations', see the Memorandum by the Office of Legal Affairs on the use of the terms 'declaration' and 'recommendation', UN Document E/CN.4/L.610 (2 April 1962), quoted in the Report of the 18th Session of the Commission on Human Rights (19 March-14 April 1962) (E/3616/Rev.1), para 105.

27 Mark E. Villiger, Customary International Law and Treaties. A Manual on the Theory and Practice of the Interrelation of Sources (2nd edn, Kluwer Law International 1997) 124.

28 Alan Boyle, 'International Lawmaking: Towards a New Role for the Security Council?' in Antonio Cassese (ed), Realizing Utopia: The Future of International Law (Oxford University Press 2012) 176.

29 Legality of the Threat or Use of Nuclear Weapons, Advisory Opinion, I.C.J. Reports 1996, 226.

$30 \quad$ Ibid para 70.

31 Boyle and Chinkin (n 1 ) 116. 
are the principal legal bodies responsible for the codification and progressive development of international law; ${ }^{32}$ they are both serviced by the Codification Division of the Office of Legal Affairs under the Secretary General.

Moreover, by means of Article 24 of the UN Charter, Member States conferred on the Security Council 'primary responsibility for the maintenance of peace and security'. Most importantly, Members agreed to 'accept and carry out decisions of the Security Council' in accordance with the UN Charter (Article 25). Although there is no legislature in the UN system, the Security Council may make binding decisions on Member States. In the Tadic case, the Appeals Chamber recognized that the Security Council has a limited power to make binding decisions when acting under Chapter vII of the UN Charter; 'it makes decisions binding by virtue of Article 25 of the Charter'. ${ }^{33}$ Article 25 as well as Article 27 of the UN Charter use the term 'decisions' as generic. The instruments adopted by the Security Council according to Article 25 are resolutions. ${ }^{34}$

Furthermore, the Ecosoc may prepare or initiate 'studies and reports with respect to international economic, social, cultural, educational, health and related matters, and may make recommendations' to the General Assembly, the Member States or the specialized agencies on such matters (Article 62(1) of the UN Charter). It may make recommendations 'for the purpose of promoting respect for, and observance of, human rights' (Article 62(2)), and 'prepare draft conventions for submission to the General Assembly, with respect to matters falling within its competence' (Article 62(3)). Once again, the Charter uses the generic term 'decisions' (Article 67); in practice, these decisions deal with procedural questions such as internal elections, nominations, confirmations and appointments, provisional agendas, etc. By means of resolutions and reports, the ECOSOC provides recommendations and draft provisions to the General Assembly.

Within Ecosoc, the UN Economic Commission for Europe (UNECE) has been particularly active as a platform for the development of legal instruments, both binding (such as conventions, agreements and regulations) and

32 See $<$ http://legal.un.org/cod $>$, accessed 10 December 2016.

33 Prosecutor v. Tadic, Appeal on Jurisdiction, No. IT-94-1-AR72, para 43 (Oct. 2, 1995), 35 ILM 32 (1996), cited in Stefan Talmon, 'The Security Council as World Legislature' (2005) 99 The American Journal of International Law 175 .

34 With the adoption of Resolution 1373, following the attacks on the World Trade Centre in New York and the Pentagon in Washington DC on 11 September 2001, the Security Council passed a series of resolutions hailed as embodying new law. On the discussion about this new phase of the Security Council, see, e.g., Chesterman et al, Law and Practice of the United Nations: Documents and Commentary (Oxford University Press 2008). 
non-binding (such as guidelines, recommendations and standards), at regional level. ${ }^{35}$ UNECE's normative work is especially prominent in the area of transport, with more than $5^{0}$ agreements and conventions, ${ }^{36}$ and regular updating of related vehicle regulations. As for non-binding tools, the most productive area of work is trade facilitation and electronic business. Most UNECE's instruments are available in its three official languages: English, French and Russian.

Finally, the Un Commission on International Trade Law (UNCITRAL), established by the General Assembly in 1966 as the main Un body for the promotion of international commercial law harmonization, also produces conventions that are binding on their signatories, as well as a significant proportion of nonbinding texts (model laws and provisions, legal guides and recommendations) in the official languages of the UN. ${ }^{37}$

\subsection{Law-Making at the WTo}

The main function of the WTO is to act as a forum for rule-making on international trade primarily through the WTO agreements, which are negotiated by the world's trading nations and ratified in their parliaments. ${ }^{38}$ They entail the exchange of trade policy commitments. The Agreement Establishing the Wто (or the 'Wто Agreement') is at the top of the wто legal hierarchy. It integrates, as annexes, several agreements on trade in goods (including, among others, agreements on agriculture, anti-dumping, safeguards, subsidies and countervailing measures, sanitary and phytosanitary measures, import licensing and technical barriers to trade), the General Agreement on Trade in Services (GATS), the Agreement on Trade-Related Aspects of Intellectual Property Rights (тRIPS), the Dispute Settlement Understanding (DSU), the Trade Policy Review Mechanism and four plurilateral agreements (not signed by all

35 See OECD/UNECE, International Regulatory Co-operation and International Organisations: The Case of the United Nations Economic Commission for Europe (UNECE) (OECD and UNECE 2016).

36 See $<$ http://www.unece.org/index.php?id=26749>, accessed 30 December 2016.

37 On the relevance of UNCITRAL's non-binding instruments as a common reference for domestic law-making and international commercial transactions, see, e.g., Henry Deeb Gabriel, "The advantages of soft law in international commercial law: the role of UNIDROIT, UNCITRAL, and the Hague Conference' (2009), 34 (3) Brooklyn Journal of International Law 655. For the status of UNCiTRAL's conventions and model laws, see: $<$ https://www .uncitral.org/pdf/english/TAC/Status/Overview-Status-Table.pdf>, accessed 10 December 2016.

38 <https://www.wto.org/english/thewto_e/whatis_e/whatis_e.htm>, accessed 10 December 2016. 
Members). ${ }^{39}$ Countries' schedules of trade commitments are also part of the agreements.

The negotiation of new multilateral agreements (or the renegotiation of provisions) is a long process of consensus-building that takes place through various Wто bodies (including the General Council, the Council for Trade in Goods, the Council for Trade in Services and the Council for TRIPS) and subsidiary committees (particularly, the Trade Negotiations Committee) and working groups. ${ }^{40}$ The multilingual drafts and reports produced in this process prepare the ground for final negotiations at the Ministerial Conference, the WTO's highest decision-making body, which meets at least once every two years.

In addition, the Ministerial Conference can define, modify or waive legally binding obligations by adopting authoritative interpretations, amendment decisions or waiver decisions according to $\operatorname{Articles} \operatorname{Ix}(2), x(1)$ and $\operatorname{Ix}(3)$ of the WTo Agreement, respectively. ${ }^{41}$

Other declarations and decisions may attain some degree of legal force. The Ministerial Conference can make 'decisions on all matters under any of the multilateral trade agreements' (Article IV(1) of the wTo Agreement). The binding force of these declarations and decisions has been addressed in some WTo dispute settlement cases. For example, in US - Lead and Bismuth II, both the Panel and the Appellate Body concluded that a Ministerial Declaration is a mere 'Declaration'42 and it is 'couched in hortatory language, ${ }^{43}$ and therefore not capable of imposing binding obligations on Members. Moreover, ministerial decisions have been used to support an argument. For example, in Turkey-Textiles, the Panel confirmed its argument by referring to a ministerial decision ('This is also reflected in paragraph 7 of the Singapore Ministerial Decision') ${ }^{44}$ and a ministerial declaration ('We also recall the Singapore Ministerial Declaration' $).{ }^{45}$ As a result, although not formally binding, ministerial declarations and decisions have been invoked as an aid to interpretation

39 <https://www.wto.org/english/docs_e/legal_e/legal_e.htm>, accessed 10 December 2016.

40 Fernando Prieto-Ramos, 'Legal Translation at the World Trade Organization', in Anabel Borja-Albi and Fernando Prieto-Ramos (eds), Legal Translation in Context: Professional Issues and Prospects (Peter Lang 2013) 263.

41 See, e.g., Isabel Feichtner, 'The Waiver Power of the wто: Opening the wTo for Political Debate on the Reconciliation of Competing Interests' (2009) 20 The European Journal of International Law 615 .

42 Panel Report, Us - Lead and Bismuth II (1999), WT/DS138/R, para VI.3.

43 Appellate Body Report, Us - Lead and Bismuth II (2000), WT/DS138/AB/R, para 49.

44 Panel Report, Turkey - Textiles (1999), WT/DS34/R, para 9.100.

45 Ibid para 9.162. 
and can be considered to contribute to WTO rule-making. Finally, according to paragraph 2 of Article IV of the WTо Agreement, 'in the intervals between meetings of the Ministerial Conference, its functions [are] conducted by the General Council', which also carries out its specific tasks.

\subsection{Law-Making at the EU}

The EU differs from the UN and the WTO in that it is a supranational organization that produces binding and directly applicable legislation (see section 2 above). It addresses both Member States and individuals. Article 288 of the Treaty on the Functioning of the European Union (TFEU) is the foundational provision on the different types of $\mathrm{EU}$ instruments:

To exercise the Union's competences, the institutions shall adopt regulations, directives, decisions, recommendations and opinions. A regulation shall have general application. It shall be binding in its entirety and directly applicable in all Member States.

A directive shall be binding, as to the result to be achieved, upon each Member State to which it is addressed, but shall leave to the national authorities the choice of form and methods.

A decision shall be binding in its entirety. A decision which specifies those to whom it is addressed shall be binding only on them.

Recommendations and opinions shall have no binding force.

The place of regulations, directives and decisions within the legal hierarchy depends on whether they are legislative, delegated or implementing acts. ${ }^{46}$ Legislative acts are adopted by the ordinary legislative procedure or a special legislative procedure (Article 289 of the TFEU); delegated acts are adopted by the Commission to supplement or amend non-essential elements of legislative acts (Article 290); and implementing acts are also generally adopted by the Commission or, in specific cases, by the Council (Article 291). In the framework of the legislative procedures, proposals and drafts from the European Commission and other preparatory documents (in particular, positions of the European Parliament and positions of the Council of the EU with a view to the adoption of legislation) are translated into the EU languages by the different institutions involved. The European Parliament also publishes other

46 Paul Craig and Gráinne de Búrca, EU Law: Text, Cases, and Materials (Oxford University Press 2015) 116. On the contextualisation of Commission non-legislative decisions on compliance cases, see section 4.3 below. 
TABLE 1 Main textual genres translated in law-making procedures

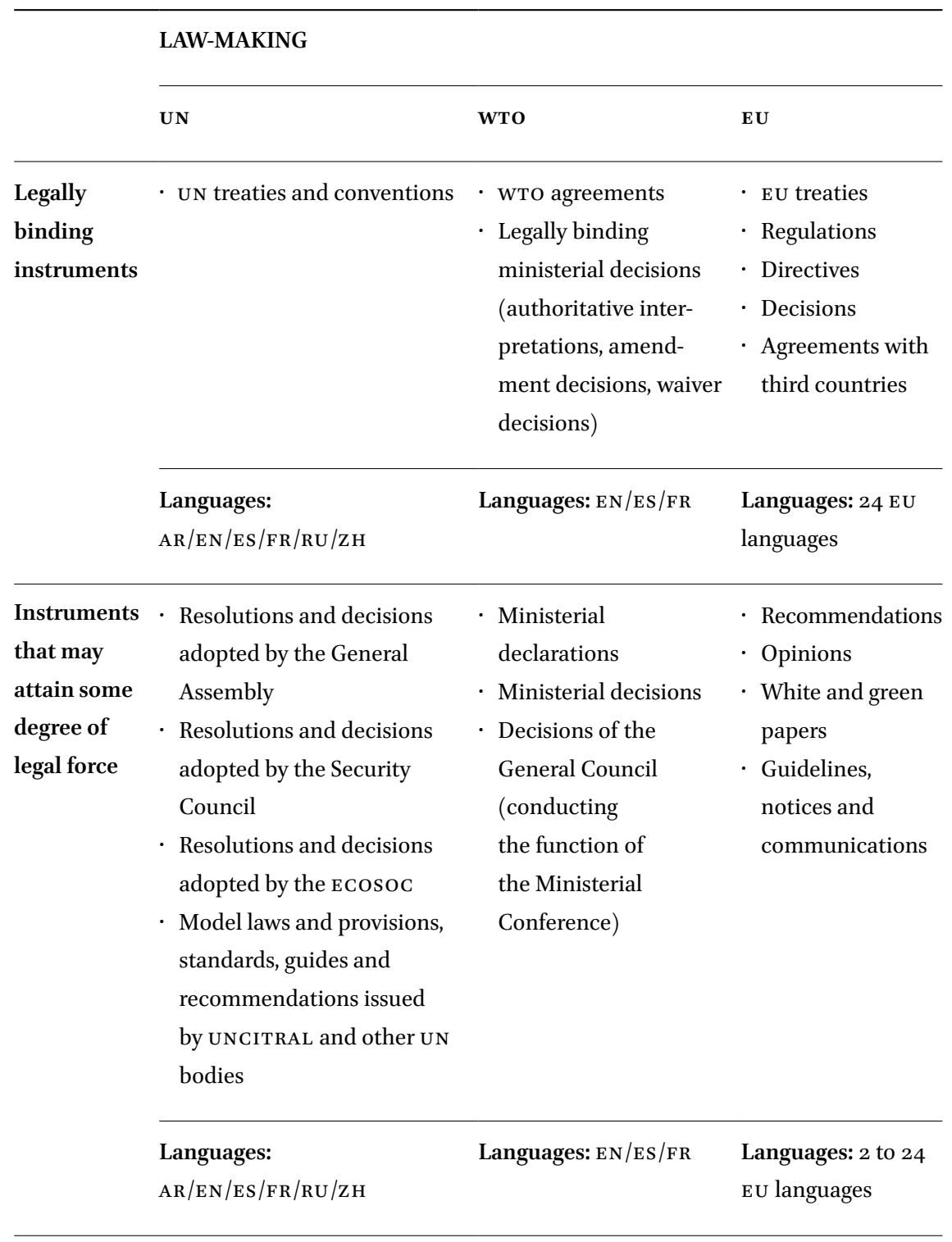

multilingual documents (such as reports and motions for resolutions) that can be used as input to law-making.

According to Article 288, recommendations and opinions have no binding force. They can be referred to the CJEU with regard to their interpretation or validity but 'they cannot create rights upon which individuals may rely before 
a national court'. ${ }^{47}$ However, the national courts 'are bound to take recommendations into consideration in order to decide disputes submitted to them, in particular where they cast light on the interpretation of national measures adopted in order to implement them or where they are designed to supplement binding Community provisions.' ${ }^{48}$

Recommendations and opinions can therefore be considered as forms of soft law. Other forms include policy guidelines issued by the Commission on mergers or State aids, which also relate to monitoring measures (see section 4.3 below). Guidelines and other benchmarking documents are also produced in the so-called 'open method of coordination', a non-binding intergovernmental policy coordination mechanism monitored by the Commission. ${ }^{49}$

In this section, the focus is on texts produced in the context of procedures of surveillance of Member States' compliance with the different binding instruments, including reporting obligations. Texts on policy implementation or coordination not involving legal obligations (including working programs, strategic plans and other administrative documents) were considered secondary to the main genres used in compliance monitoring.

\subsection{Monitoring at the UN}

Enforcement and compliance issues constitute one of the most complex subjects of international law. ${ }^{50}$ Many multilateral agreements establish a body to monitor how the parties comply with the agreement provisions. Conferences of the State Parties (or Meetings of State Parties) are among these bodies. ${ }^{51}$ They can be established in the treaty itself or may be convened at a later stage by the UN 'or one of its specialized agencies, or by a commission established

47 Case C-322/88 Salvatore Grimaldi v Fonds des maladies professionnelles [1989] ECR 646, para 16.

48 Ibid para 18.

49 See <http://www.europarl.europa.eu/EPRS/EPRS-AaG-542142-Open-Method-of-Coordi nation-FINAL.pdf>, accessed 30 November 2016.

50 Schachter (n 23) 13-14.

51 See, e.g., Conference of the Parties to the United Nations Framework Convention on Climate Change (UNFCCC), among other environmental treaty monitoring bodies: <http:// research.un.org/en/docs/environment/treaties>, accessed 10 December 2016. 
to manage the treaty'52 They are responsible for the ongoing review of the relevant agreements and adopt measures, including of a legal nature, to further their purpose.

Other treaty monitoring bodies include committees, commissions, working groups and other subsidiary bodies established under specific resolutions or conventions. They often use reports on implementation and a diversity of other documents (e.g., comments, letters, notes verbales) to fulfill their functions. In the case of the Security Council, sanctions committees are an important tool to enforce decisions; other subsidiary bodies include, for example, the Security Council Working Group on Children and Armed Conflict, established in 2005 under resolution 1612 to supervise a new monitoring and reporting mechanism on related violations.

However, the most prolific production of multilingual texts on compliance monitoring is found in connection with international human rights treaties. Treaty monitoring bodies include, among others: the Human Rights Committee, which monitors implementation of the International Covenant on Civil and Political Rights (CCPR); the Committee on the Elimination of Discrimination against Women, which monitors implementation of the Convention on the Elimination of All Forms of Discrimination against Women (CEDAW); and the Committee on the Elimination of All Forms of Racial Discriminations, which monitors implementation of the Convention on the Elimination of All Forms of Racial Discrimination (CERD). ${ }^{53}$

Members of these committees are elected for their individual expertise. Their functions are determined by the provisions of their respective treaties: they examine State parties' periodic reports and individual complaints, conduct country inquiries, organize thematic discussions and adopt general comments on treaty provisions. ${ }^{54}$ The instruments and opinions issued by the human rights treaty bodies are not formally binding, but their repetition creates interpretation patterns that exert considerable influence. 'When supplemented by the reports and recommendations of special rapporteurs, working groups and independent experts, a body of persuasive jurisprudence is developed. ${ }^{55}$

\footnotetext{
$5^{2} \quad$ Boyle and Chinkin ( $\mathrm{n} 1$ 1) 151.

53 See list of ten human rights treaty bodies: <http://www.ohchr.org/EN/HRBodies/Pages/ HumanRightsBodies.aspx $>$, accessed 30 November 2016.

54 <http://www.ohchr.org/EN/HRBodies/Pages/WhatTBDo.aspx >, accessed 30 November 2016. 
The monitoring procedures of the Human Rights Council (HRC), as the primary intergovernmental body in the field, deserve specific attention. The HRC's special procedures are 'independent human rights experts with mandates to report and advise on human rights from a thematic or country-specific perspective. ${ }^{56}$ They carry out country visits and send communications to States, intergovernmental organizations or non-State actors to request action with regard to human rights violations. Special procedure mechanisms include: special rapporteurs, special representatives, independent experts and working groups. They produce annual reports for the HRC and also, in most cases, for the General Assembly, and may report to other bodies. ${ }^{57}$

Finally, the Universal Periodic Review (UPR) involves a periodic review of the human rights records of all UN Member States. ${ }^{58}$ Each review is conducted by the UPR Working Group ( 47 members of the HRC) with the assistance of three States ('troikas'), who serve as rapporteurs. Apart from examining States' human rights records and human rights violations, the aim of the UPR is also to provide technical assistance to States and to share best practices in the field of human rights. ${ }^{59}$ The reviews are based on various documents that are systematically translated: the 'national report' (provided by the State under review); the 'compilation of UN information' (provided by human rights experts and UN entities); the 'summary of stakeholders' information' (including national human rights institutions and non-governmental organizations); and the Report of the Working Group (or 'outcome report'), which summarizes the proceedings of the review process and includes conclusions and/or recommendations. ${ }^{60}$ Some background information and questions submitted by other States, however, are normally available only in the language of the country under review and/or English.

The investigative nature of most of these monitoring processes and the absence of an international court of human rights further contribute to their being perceived as quasi-judicial procedures for promoting human rights standards. ${ }^{61}$

$5^{6}<$ http://www.ohchr.org/EN/HRBodies/SP/Pages/Welcomepage.aspx>, accessed 30 November 2016.

57 Ibid.

$58<$ http://www.ohchr.org/EN/HRBodies/UPR/Pages/BasicFacts.aspx >, accessed 30 November 2016.

59 Ibid.

6o UPR documentation gateway: <http://www.ohchr.org/EN/HRBodies/UPR/Pages/Docu mentation.aspx $>$, accessed 30 November 2016.

61 Prieto-Ramos (n 6) 316. 


\subsection{Monitoring at the WTO}

Many of the WTO agreements contain obligations for member governments to notify trade measures. One of the main functions of the WTO bodies is to ensure that these requirements are met. Notifications are instrumental to keep the WTO, its Members and stakeholders informed of specific measures, policies or legislation. In areas such as sanitary and phytosanitary matters, these notifications, which are systematically published in the three wTо languages, contain technical information that is relevant to national authorities, exporters or importers, and ultimately consumers. ${ }^{62}$

Reporting obligations are considered essential to enhance transparency at the organization. In the framework of the Doha Round of trade negotiations, launched by the Doha Ministerial Conference in 2001, these obligations have been reinforced in areas such as TRIPS, particularly in response to implementation issues raised by developing countries. ${ }^{63}$

In addition to the reporting obligations under the different wто agreements, the Wто conducts reviews of its Members' trade policies: the trade policy reviews (TPRs). The wTo General Council meets as the Trade Policy Review Body (TPRB) to carry out these reviews and 'to consider the DirectorGeneral's regular reports on trade policy development'.64 All Members' policies are subject to this monitoring, but the frequency of the reviews depends on their share of world trade. Policies of the biggest four, or the 'Quad' (the EU, the United States, Japan and China), are examined every two years; the next 16 countries are reviewed every four years; and the remaining, every six years. ${ }^{65}$ The reviews promote compliance by WTO Members and contribute to the multilateral debate on trade policies. The main documents translated in each TPR procedure are the government report and the Secretariat report, which are published together with the relevant proceedings (minutes of the TPRB meetings, and questions and answers by wTO Members). Press releases on the reviews are also published in the three languages. ${ }^{66}$

62 See dedicated gateway: <http://spsims.wto.org/Default.aspx>, accessed 30 November 2016.

63 See the Doha implementation ministerial decision of 14 November 2001 ('Implementation-related issues and concerns', WT/MIN(01)/17).

64 <https://www.wto.org/english/tratop_e/tpr_e/tprbdy_e.htm>, accessed 30 November 2016.

65 <https://www.wto.org/english/thewto_e/whatis_e/tif_e/agrmu_e.htm>, accessed 30 November 2016.

66 See TPR gateway: <https://www.wto.org/english/tratop_e/tpr_e/tpr_e.htm>, accessed 30 November 2016. 


\subsection{Monitoring at the $\mathrm{E} U$}

According to Article 17(1) of the Treaty on European Union (TEU), the Commission 'shall ensure the application of the Treaties, and of measures adopted by the institutions pursuant to them', and it 'shall oversee the application of Union law under the control of the Court of Justice of the European Union'. The Commission, often called the 'Guardian of the Treaties', is in charge of: (a) monitoring compliance with EU law in general, and (b) monitoring the implementation of directives.

The Commission applies various mechanisms to monitor the application of $\mathrm{EU}$ law in general. It conducts investigations on issues raised by EU citizens and organizations (in complaints) or by members of the European Parliament (petitions, enquiries or questions). In these investigations, the Commission can use reports submitted by Member States (in compliance with reporting obligations under EU legislation) and other relevant documents. ${ }^{67}$ These texts are registered and assessed by the Commission, but are not translated for publication purposes, except for summaries of petitions.

As for monitoring of the implementation of directives, the Commission verifies Member States' transposition measures in order to ensure that the directives achieve the results required. ${ }^{68}$ In case of failure to notify transposition measures or incomplete measures, the Commission can undertake infringement proceedings for non-communication. The national transposition measures and the notifications by Member States and the Commission are not systematically translated for publication. However, national legislation tends to be translated into English for internal monitoring purposes. ${ }^{69}$

If the Commission identifies a possible infringement of $\mathrm{EU}$ law, it attempts to solve the underlying problem with the Member State through a structured dialogue (EU Pilot). ${ }^{70}$ In case of disagreement on a possible solution, the Commission can initiate a formal infringement procedure (Articles 258-26o of the TFEU). Article 258 of the TFEU provides that: 'If the Commission considers that a Member State has failed to fulfil an obligation under the Treaties, it shall

67 See, e.g., in the environment policy area: <http://ec.europa.eu/environment/legal/law/ complaints.htm>, accessed 30 November 2016.

68 National implementing measures can be found in EUR-Lex: <http://eur-lex.europa.eu/ collection/n-law/mne.html?locale $=$ en $>$, accessed 30 November 2016.

69 European Commission informants confirmed that this legislation actually accounts for a significant proportion of translation work into English at the Directorate-General for Translation.

$70<$ https://ec.europa.eu/info/infringement-procedure_en>, accessed 30 November 2016. 
deliver a reasoned opinion on the matter after giving the State concerned the opportunity to submit its observations'.

This provision is very general in its description of a Member State violation for the purpose of enforcement proceedings. The infringement may result from both an action (active behavior) and an omission (inaction) on the part of the Member States: non-conformity/non-compliance, failure to notify, incorrect/bad application. ${ }^{71}$ In addition, Member States can also bring an action against another Member State for an alleged infringement of an obligation under the Treaties (Article 259 of the TFEU).

The documents issued in infringement procedures are not all translated or publicly available. For example, letters of formal notice and reasoned opinions are only drafted in the languages of the Member States to which they are addressed, while referrals to the CJEU (see section 5.3 below) are only fully translated into French, but they are not available to the public. However, these key documents are summarized in all the official languages in fact sheets on the Commission's infringement decisions (see also the Eu's legal acts in section 3.3). ${ }^{72}$ These fact sheets are accessible from the Commission's press release database through the Commission's infringement gateway. ${ }^{73}$ In some cases, particularly letters of formal notice and referrals to the Court, the summaries refer to a full press release that is only available in the Commission's three procedural languages (English, French and German) plus the languages of the countries affected by the decisions if their official languages are different from the procedural ones. ${ }^{74}$

An important area of monitoring by the Commission is that of competition policy enforcement (as provided for in Articles 101-109 of the TFEU), which follows specific procedures under the responsibility of the Directorate-General for Competition. These procedures cover cases in the areas of antitrust and

71 See European Commission, Monitoring Application of Union Law, Annual Report 2014, <http://ec.europa.eu/atwork/applying-eu-law/docs/annual_report_32/com_2015_329 _en.pdf $>$, accessed 30 November 2016.

72 See, e.g., the fact sheet published on 8 December 2016: 'December infringements package: key decisions': <http://europa.eu/rapid/press-release_MEMO-16-4211_EN.htm>, accessed 12 December 2016. $<$ http://ec.europa.eu/atwork/applying-eu-law/infringements-proceedings/infringement_decisions $>$, accessed 30 November 2016.

74 For example, in the case of 'Car emissions: Commission opens infringement procedures against 7 Member States for breach of EU rules', the full press release is also available in Czech, Greek, Lithuanian and Spanish: <http://europa.eu/rapid/press-release_IP-16-4214 _en.htm>, accessed 12 December 2016. 
cartels, mergers and State aid. ${ }^{75}$ Not all documents are publicly available or translated in these cases, especially when sensitive corporate information cannot be disclosed. Openings of proceedings and memos tend to be published in English only, while summary decisions, Advisory Committee opinions and Hearing Officer reports are published in all the official languages. Press releases are published in English or the three procedural languages of the Commission plus the language of the affected Member State (if this is different from the procedural languages). Prohibition decisions in antitrust and cartel cases are fully published in English and the languages of the countries affected; in the case of decisions on merger procedures, only the English text is available and authentic. ${ }^{76}$ The dedicated database entries state that these publications are for information purposes and should not be considered official publications. ${ }^{77}$ As in the case of other compliance procedures conducted by the Commission, the translation and publication policy seems to ensure enhanced access to essential information that might create procedural rights for different stakeholders, while other information remains internal until it is eventually made publicly available as part of court proceedings.

The decisions adopted by the Commission in these cases can be classified as non-legislative acts (see section 3.3). They take effect on their addressees (generally non-compliant companies and national authorities) upon notification, and can be appealed to the CJEU. ${ }^{78}$ This and the fact that they derive from specific investigations actually make them comparable to other legal genres resulting from monitoring or even adjudicative procedures in terms of function and content. In fact, like the UN monitoring bodies in the area of human rights, the investigative powers of the Commission in these cases can be regarded as 'quasi-judicial' or 'pre-judicial'.

Finally, to ensure compliance with (WTO-consistent) EU trade rules, the Commission's Directorate-General for Trade coordinates the conduct of trade defense investigations, including anti-dumping, anti-subsidy and safeguard

75 See European Commission, The EU Explained: Competition - Making Markets Work Better (Publications Office of the EU 2014).

76 For example, in the Commission's cartel prohibition decision in the case сомР/39.396 (Calcium carbide and magnesium based reagents for the steel and gas industries), only the English, German, Slovak and Slovene languages are authentic.

77 Database available at: <http://ec.europa.eu/competition/elojade/isef/>, accessed 30 November 2016.

78 See <http://eur-lex.europa.eu/legal-content/EN/TXT/?uri=uriserv:aioo36>, accessed 30 November 2016. 


\section{MONITORING}

UN WTO WU

\section{Monitoring by Conferences of State}

Parties, committees, commissions and other subsidiary bodies:

- Parties' Reports

- Information from other sources

- Concluding observations from the treaty bodies

- Complaints by individuals and State-toState complaints

- Country enquiries

- General comments or general recommendations

- Decisions, notes verbales and letters

- Statements, summary records and official records

\section{Special procedures:}

- Annual reports to the Human Rights Council

- Annual reports to the General Assembly

- Communications and other working documents

\section{Universal Periodic Review:}

- National reports

- Compilations of UN information

- Summaries of stakeholders' information

- Working Group (outcome) reports

\section{Monitoring under Monitoring of compliance with EU law} different wTo in general: agreements and Petitions from the European Parliament decisions: (publicly accessible summaries)

- Notifications · Reports

- Reports

- Questions and

Infringement procedures:

answers

- Letters of formal notice*

- Reasoned opinions*

Trade Policy - Referrals to the CJEU*

Review:

- Case closures*

- National reports [* Publicly accessible summaries in fact

- Secretariat sheets or full press releases] reports

- Minutes of

\section{Competition rule enforcement cases} review meetings (antitrust and cartel, mergers, State aid):

- Questions and · Advisory Committee opinions answers $\cdot$ Hearing Officer reports

- Press releases - Press releases

\section{Trade defense investigations}

(anti-dumping, anti-subsidy, safeguard):

- Notices of the initiation or termination of proceedings

- Notices of other measures

- Summaries of requests and proceedings

- Annual reports 
procedures. ${ }^{79}$ Different notices and summaries are published in the Official Journal of the UE (in all the official languages) as part of these procedures, which usually lead to law-making in the form of regulations or decisions by the Commission or the Council of the EU. The measures detailed in these provisions are often directly related to WTO dispute settlement recommendations (see section 5.2 below). In fact, this policy area clearly illustrates the connection between compliance monitoring, law-making and adjudication, as well as the EU's position in ensuring legal implementation between its Member States and multilateral fora.

Text Production in Adjudication Procedures

Adjudication includes the settlement of disputes or interpretation problems that arise in the implementation of legal instruments. Through their decisions, adjudicative bodies contribute to the uniform interpretation of these instruments. To this end, they may also conduct advisory proceedings initiated by other institutional bodies (e.g., in the case of the UN) or by national courts (in the case of the CJEU).

\subsection{Adjudication at the UN}

In many fields of UN work, applying and interpreting law 'take place continually' and are 'the main way in which law develops, whether case by case, or by new rules that add more specific meanings to existing law' 80 The ICJ, the principal judicial organ of the UN, settles disputes submitted by States according to international law, and gives advisory opinions on legal questions referred to it by UN bodies and specialized agencies. ${ }^{81}$ As pointed out in section 2, the ICJ works in English and French, which means that any argumentation related to multilingual UN instruments or international treaties must be expressed in those two official languages, thereby restricting the accessibility to ICJ decisions as opposed to the UN six-language regime.

In contentious cases, 'only states may be parties in cases before the Court' (Article 34(1) of the ICJ Statute). "The jurisdiction of the Court comprises all cases which the parties refer to it and all matters specially provided for in the

79 See, e.g., an overview of the anti-dumping investigation procedure at: <http://trade .ec.europa.eu/doclib/docs/2013/april/tradoc_151020.pdf>, accessed 30 November 2016.

$80 \quad$ Schachter (n 23) 9 .

$81<$ <ttp://www.icj-cij.org/court/index.php?p1=1>, accessed 30 November 2016. 
Charter of the United Nations or in treaties and conventions in force' (Article $36(1)$ of the ICJ Statute). Article 36(2) also provides that the States parties to the ICJ Statute (all Members of the UN) may at any time declare that they recognize the jurisdiction of the Court 'as compulsory ipso facto and without special agreement'. Article 38 of the ICJ Statute defines the scope of applicable international law:

a. international conventions, whether general or particular, establishing rules expressly recognized by the contesting states;

b. international custom, as evidence of a general practice accepted as law;

c. the general principles of law recognized by civilized nations;

d. subject to the provisions of Article 59, judicial decisions and the teachings of the most highly qualified publicists of the various nations, as subsidiary means for the determination of rules of law.

According to Article $38(1)(d)$, the Court is to apply judicial decisions 'as subsidiary means for the determination of rules of law'. This is subject to the provisions of Article 59, which states that 'the decision of the Court has no binding force except between the parties and in respect of that particular case'. This means that decisions of the ICJ do not have the status of precedents (stare decisis).

When settling legal disputes, the ICJ can issue court orders and judgments. Individual judges or groups of judges may write separate or dissenting opinions. Apart from judgments and orders, and summaries thereof, in contentious cases, other documentation published in English and French include incidental, written and oral proceedings, as well as press releases. ${ }^{82}$

Judicial interpretation of a treaty by the ICJ may also be initiated through a request for an advisory opinion. Under Article 96(1) of the UN Charter: 'The General Assembly or the Security Council may request the International Court of Justice to give an advisory opinion on any legal question'. In addition, Article 96(2) allows the General Assembly to authorize other organs of the United Nations and specialized agencies to request opinions on legal questions arising within the scope of their activities'.

In advisory proceedings, the ICJ issues orders and advisory opinions in English and French. As in the case of contentious proceedings, the Court determines which is the authoritative language of each case (see section 2 above),

82 Case documentation is accessible through: <http://www.icj-cij.org/docket/index.php? p1 $=3>$, accessed 30 November 2016 . 
and individual judges or groups of judges may issue separate or dissenting opinions. Oral and written statements, as well as press releases, are also regularly translated in advisory proceedings.

\subsection{Adjudication at the WTO}

The WTо dispute settlement mechanism is a crucial pillar of the organization's work and stands out as a successful system within the landscape of international courts. ${ }^{83}$ Its objective is described in Article 3.2 of the DsU:

The dispute settlement system of the WTO is a central element in providing security and predictability to the multilateral trading system. The Members recognize that it serves to preserve the rights and obligations of Members under the covered agreements, and to clarify the existing provisions of those agreements in accordance with customary rules of interpretation of public international law. Recommendations and rulings of the DSB cannot add to or diminish the rights and obligations provided in the covered agreements.

Trade disputes are settled by panels, the Appellate Body and the Dispute Settlement Body (DSB). Complaining Members must bring any dispute arising under the covered agreements to the WTO. Article 23.1 of the DSU ensures WTO's exclusivity vis-a-vis other international organizations, and protects the multilateral system from unilateral conduct'. ${ }^{84}$ However, this is compatible with the possibility of using alternative dispute resolution methods, which can be 'undertaken voluntarily if the parties to the dispute so agree', and 'may be requested at any time by any party to a dispute' (Articles $5.1-5.3$ of the DSU) ${ }^{85}$ Unlike the ICJ and the CJEU, the WTO dispute settlement only deals with contentious cases. Neither panels nor the Appellate Body are encouraged 'to "make law" by clarifying existing provisions of the WTO Agreement outside the context of resolving a particular dispute. ${ }^{86}$

Although the procedure resembles court proceedings, 'the preferred solution is for the countries concerned to discuss their problems and settle the

83 See, e.g., Donald McRae, 'The wTo Appellate Body: A Model for an ICsid Appeals Facility?' (2010) 1 (2) Journal of International Dispute Settlement 371.

84 Peter Van den Bossche and Werner Zdouc, The Law and Policy of the World Trade Organization (3rd edn, Cambridge University Press 2013) 160.

85 Isabelle Van Damme, Treaty Interpretation by the wTo Appellate Body (Oxford University Press 2009) 5 .

86 Appellate Body Report, us - Wool Shirts and Blouses (1997), WT/DS33/AB/R, 19. 
dispute by themselves'. ${ }^{87}$ If consultations between the Members in the dispute do not succeed, a panel of independent experts may be established by the DSB at the request of the complaining party. The DSB adopts the panel report 'unless a party to the dispute formally notifies the DSB of its decision to appeal or the DSB decides by consensus not to adopt the report' (Article 16.4 of the DSU). In case of appeal proceedings, the Appellate Body may uphold, modify or reverse the panel's conclusions in its report, which is also adopted by the DSB unless a decision is made by consensus not to do so (Article 17.14 of the DSU).

Conclusions and recommendations contained in panel and Appellate Body reports are binding upon the parties to the dispute. However, in JapanAlcoholic Beverages II, the Appellate Body held that panel reports are often considered by subsequent panels. "They create legitimate expectations among wто Members, and, therefore, should be taken into account where they are relevant to any dispute. 88

The DSB is responsible for verifying the implementation of recommendations made in the reports, where relevant. Situations of disagreement between the parties on the implementation period or on the WTO-conformity of the implementing measures may lead, respectively, to binding arbitration (Article 21.3 of the DSU) or to a compliance panel, the original panel whenever possible (Article 21.5 of the DSU). In case of subsequent disagreement on the level of compensation or suspension of concessions as a result of non-compliance, the matter must be referred to arbitration according to Article 22.6 of the DSU. ${ }^{89}$

\subsection{Adjudication at the $\mathrm{EU}$}

The CJEU is the judicial institution of the EU. It consists of two courts of law: the Court of Justice proper and the General Court. The Civil Service Tribunal was dissolved on 1 September 2016 after its jurisdiction was assigned to the General Court. ${ }^{90}$ The CJEU's primary task is to 'review the legality' of acts of the EU institutions and to 'ensure the uniform interpretation and application of EU law'. To this end, 'the Court has been given clearly defined jurisdiction, which it exercises on references for preliminary rulings and in various

87 <https://www.wto.org/english/thewto_e/whatis_e/tif_e/disp1_e.htm>, accessed 30 November 2016.

88 Appellate Body Report, Japan - Alcoholic Beverages II (1996), WT/DS8/AB/R/WT/DS10/AB / $\mathrm{R} / \mathrm{WT} / \mathrm{DS} 11 / \mathrm{AB} / \mathrm{R}, 14$.

89 For an example of a long dispute and a full list of documents issued between initial consultations and arbitration proceedings, see, e.g., European Communities - Regime for the Importation, Sale and Distribution of Bananas: <https://www.wto.org/english/tratop_e/ dispu_e/cases_e/ds27_e.htm>, accessed 30 November 2016.

$90<$ http://curia.europa.eu/jcms/jcms/Jo2_6999/en/>, accessed 15 March 2017. 
categories of proceedings. ${ }^{91}$ Article $19(3)$ of the TEU provides that the CJEU shall, in accordance with the Treaties:

(a) rule on actions brought by a Member State, an institution or a natural or legal person;

(b) give preliminary rulings, at the request of courts or tribunals of the Member States, on the interpretation of Union law or the validity of acts adopted by the institutions;

(c) rule in other cases provided for in the Treaties.

Indirect actions originate and terminate before national courts (requests for a preliminary ruling), while direct actions originate and terminate before the CJEU. There are four main types of the latter: (1) actions for failure to fulfil an obligation brought against EU governments for not applying EU law (Articles $258-260$ of the TFEU); (2) actions for annulment against EU laws that may violate the EU treaties or fundamental rights (Article 263 of the TFEU); (3) actions against EU institutions for failure to make decisions required of them (Article 265 of the TFEU); and (4) damage actions against EU decisions or actions (Article 340 of the TFEU).

Under Eu law, 'there is no doctrine of precedent': previous case-law is 'neither binding on the General Court, nor on national courts, nor on itself', ${ }^{92}$ However, for many reasons, especially legal certainty, the CJEU is 'reluctant to depart from the principles laid down in earlier cases', as these provide 'guidelines for subsequent cases'. Moreover, in its judgments, the CJEU has established key concepts that have subsequently become sources of Eu law. ${ }^{93}$

The common language of deliberation at the CJEU is, by custom, French. All documents lodged by the parties ${ }^{94}$ in each case are translated into French when it is not the language of the case, as are notices on the opening of proceedings, national courts' requests for a preliminary ruling and opinions of the Advocates General. The originals of opinions are written in the official language chosen by each Advocate General, which is often French, English, German, Spanish or Italian. ${ }^{95}$ Texts to be published or notified are translated as

\footnotetext{
91 <http://curia.europa.eu/jcms/jcms/Jo2_7024/en/>, accessed 30 November 2016.

92 Alina Kaczorowska, European Union Law (Routledge 2013) 140.

93 Ibid 109.

94 These documents are not published but account for an important volume of translation, particularly into French.

95 Advocates General are encouraged to use these 'pivot languages' (to facilitate subsequent translation) since the 2004-2007 EU enlargements. See Karen McAuliffe, 'Language
} 
necessary into all the official languages. Rules of Procedure, which, as opposed to the other main genres, have the form of legislation, are also updated from time to time. As in the case of the ICJ, press releases are also regularly translated into selected languages.

TABLE 3 Main textual genres translated in adjudication procedures

\section{ADJUDICATION}

\begin{tabular}{llll}
\hline UN & WTO & EU \\
\cline { 1 - 1 } $\begin{array}{l}\text { International Court of } \\
\text { Justice }\end{array}$ & $\begin{array}{l}\text { Dispute Settlement Body, } \\
\text { Panels and Appellate Body }\end{array}$ & $\begin{array}{l}\text { Court of Justice of the } \\
\text { European Union }\end{array}$
\end{tabular}

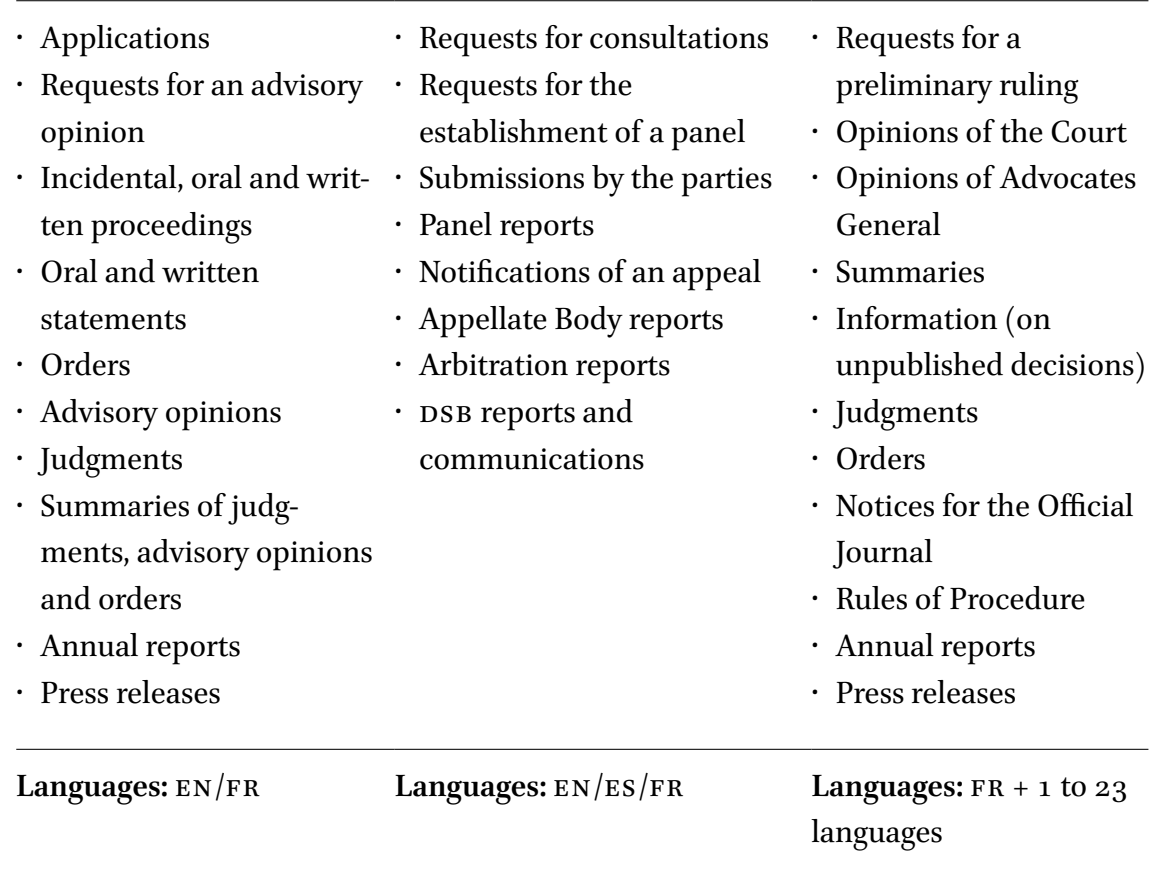

and the institutional dynamics of the Court of Justice of the European Communities: A Changing Role for Lawyer-Linguists?' in Michel Gueldry (ed), How Globalizing Professions Deal with National Languages: Studies in Cultural Conflict and Cooperation (The Edwin Mellen Press 2009) 139. On multilingualism at the Court, see also Susan Wright, 'The Language of the Law in Multilingual Contexts-Unpicking the English of the EU Courts' Judgments' (2016) 37 (2) Statute Law Review 156. 
The examination of the three contexts of text production (law-making, compliance monitoring and adjudication) and the resulting taxonomies of textual genres confirm the vast scope of legal translation within institutional translation, and its essential role in the creation and application of international and EU law. The fabric of institutional legal communication is primarily composed of translated text. Legal consistency, certainty and predictability are, therefore, also a matter of translation quality. It can even be argued that the multidimensional and multilingual dynamics of global law itself fits into the paradigm of legal translation as an exercise of communicative compromises between different legal traditions, sources, conventions and areas of expertise. ${ }^{96}$

The comparative description of legal settings of institutional text-types affirms the applicability of the threefold classification used in this study. It also confirms the interconnection between all the settings and text typologies as a network of multilingual bodies of law. This is reflected in the functions and intertextuality of specific legal genres within each category, with marked similarities between the institutions analyzed.

Despite their varying denominations, binding legal instruments, which comprise a range of law-making genres, constitute the backbone of multilingual law in these institutions. The texts of multilateral treaties and Eu legislation are equally authentic in the respective official languages of the law-making bodies. They govern an expanding number of areas of international and EU policy, and provide for a multiplicity of monitoring procedures to ensure compliance by Member countries. Monitoring generates the most heterogeneous group of texts. The most common legal genres are reports of different kinds issued by Members and monitoring bodies. Texts drafted at national level understandably account for a higher proportion of institutional translation in this context, particularly in the intergovernmental organizations, while the investigative and persuasive functions of surveillance bodies are also comparable. Finally, controversial issues arising in law application are brought to the adjudicative bodies, which perform similar roles as authoritative interpreters of multilingual legal instruments. In the $\mathrm{EU}$, the connection between the three legal settings and the different layers of national, supranational and intergovernmental policies is clearly illustrated by the area of trade, where EU monitoring of compliance with wTO-consistent EU trade rules and wTO adjudicative recommendations often lead to new binding regulations and decisions.

96 On the idea of law as translation, see François Ost, Le droit comme traduction (Presses de l'Université Laval 2009). 
In the case of the $\mathbf{U N}$, a correlation can be established between three findings: the higher proportion of instruments of limited enforceability (such as resolutions); the modest volume of ICJ texts in comparison with those of the CJEU and the wTO dispute settlement bodies; and the large amount of texts produced through the different monitoring procedures, particularly in the field of human rights. This is compounded by the high number of countries to which reporting obligations apply at the UN. Treaty bodies in this area seem to fulfil a key quasi-judicial function, as their decisions cannot be subject to subsequent court revision within the same institutional order, as opposed to the European Commission's enforcement measures.

In contrast, adjudication stands out as an extremely productive translation context at the WTO, which is explained by the prominence and success of its dispute settlement system, and the increasing dynamism of transnational trade relations in the past few decades. Finally, law-making accounts for a significantly greater share of institutional translation at the EU. The resulting legislation is more accessible to citizens in terms of multilingualism, and closer to the national level also in terms of direct applicability and enforceability. Nonetheless, the Eu legislative procedure, involving three institutions, can also be compared to multilateral law-making as regards the complexity of negotiating texts through different stages and bodies that generate multiple drafts for translation. Interestingly, the EU also has the highest proportion of texts that are not systematically translated or publicly available (other than as summaries or notices) in the context of monitoring procedures. This can be linked to the sensitive nature of the Commission's role in compliance investigations that affect authorities and companies of its Member States and can lead to court proceedings.

Overall, the similarities and differences identified through the comparative mapping of legal genres are textual manifestations of the unique character of each institutional legal system, including their degree of multilingualism and the ways in which each interacts with domestic levels of application. Further, the results confirm a clear relationship between the number of official languages and the variations of the actual translation regime followed in different legal settings. While the Wто applies its trilingual policy to all texttypes and genres, not all documents are translated into all official languages within the UN system and, especially, at the EU institutions. Official languages are reduced from six to two in the case of the ICJ (only one of them being authoritative per case). The 24 official languages of the $\mathrm{EU}$ are also reduced, sometimes drastically, in the case of many documents of the Commission's monitoring procedures and certain genres at the CJEU, where French is the working language and judgments are only authentic in the language of the 
case. The tension between EU citizens' language rights and accessibility to the law, on the one hand, and the pragmatic implications of ensuring unity and predictability of legal meaning in 24 languages, on the other, becomes particularly apparent in the context of multilingual text interpretation by the CJEU. ${ }^{97}$

The results of this study will be the basis for further quantitative and qualitative analysis of discursive features by genre, related translation strategies and professional profiles, among other aspects. The ultimate aim is to establish an empirical foundation for examining the scope, texture and actors of institutional legal translation, as a condition to improve translation quality and, hence, multilingual law text production.

\section{Acknowledgements}

I would like to thank Lucie Pacho Aljanati for her contributions to the mapping reflected in this article, as well as Diego Guzmán and Giorgina Cerutti for their technical assistance. I also thank the Swiss National Science Foundation for its support through a Consolidator Grant scheme.

97 See, e.g., Mattias Derlén, 'In Defence of (Limited) Multilingualism: Problems and Possibilities of the Multilingual Interpretation of European Union Law in National Courts', in Anne Lyse Kjær and Silvia Adamo (eds), Linguistic Diversity and European Democracy (Ashgate 2011) 143; and Susan Šarčević, 'Multilingual Lawmaking and Legal (Un)Certainty in the European Union' (2013) 3 (1) International Journal of Law, Language \& Discourse 1. 